\title{
Internalisasi pendidikan moral pada perguruan tinggi di Jepang
}

\author{
Sutrisno ${ }^{a}$ \\ a Program Studi Pendidikan Pancasila dan Kewarganegaraan, Universitas Muhammadiyah Ponorogo, \\ Ponorogo, Indonesia
}

\begin{abstract}
ABSTRAK
Penelitian ini bertujuan untuk Mengetahui konsep pembelajaran pendidikan moral di perguruan tinggi di Jepang. Penelitian ini merupakan penelitian kualitatif. Penelitian dilaksanakan di Tokyo Gakugei University. Metode penelitian yang digunakan dalam penelitian ini adalah deskriptif kualitatif. Metode pengumpulan data diperoleh dengan cara observasi, wawancara dan dokumentasi. Hasil penelitian ini menjelaskan bahwa Pendidikan moral pada perguruan tinggi di Jepang bertujuan untuk membangun karakter warga negara muda untuk berpikir bagaimana caranya hidup dan bertindak atas dasar penilaian otonom dan hidup sebagai orang yang proaktif bersama dengan orang lain. Pendidikan moral menjadi alat dan media untuk mentrasformasikan nilai-nilai dasar filosofis masyarakat Jepang. Pendidikan moral dapat tercermin pada karakter keseharian masyarakat Jepang yang memiliki etos dan semangat kerja tinggi dalam menjalankan setiap profesinya.
\end{abstract}

\section{ABSTRACT}

This study aims to determine the concept of learning moral education in universities in Japan. This research is a qualitative research. The study was conducted at Tokyo Gakugei University. The research method used in this study is descriptive qualitative. Data collection methods obtained by observation, interviews and documentation. The results of this study explain that moral education at universities in Japan aims to build the character of young citizens to think how to live and act on the basis of autonomous judgment and life as people who are proactive together with others. Moral education is a tool and media for transforming the basic philosophical values of Japanese society. Moral education can be reflected in the daily character of Japanese people who have high ethos and work spirit in carrying out every profession.
Sejarah Artikel

Diterima : 24 Februari 2020

Disetujui : 3 April 2020

Kata kunci:

Internalisasi, pendidikan moral, perguruan tinggi Jepang

\section{Keywords:}

Internalization, moral education, Japanese Universities

\section{Pendahuluan}

Perkembangan teknologi dan informasi memberikan dampak yang begitu besar bagi perkembangan negara. Teknologi dan informasi bisa menjadi media untuk membangun negara dan juga bisa menjadi ancaman bagi warga negara bangsa. Memasuki abad ke-21 peran media dan informasi sangat begitu besar pengaruhnya di berbagai bidang kehidupan manusia. Semua tidak bisa dilepaskan akan peran teknologi dan informasi sebagai pengontrol bagi berkembangnya sebuah negara. Berbagai persoalan global yang terjadi menjadi permasalahan baru bagi setiap negara untuk bisa diselesaikan secara bijak oleh setiap negara. Globalisasi menjadi pendorong utama dalam perkembangan teknologi dan informasi saat ini. Globalisasi menjadi pengaruh negatif bagi generasi muda apabila tidak dapat diantisipasi dengan baik dan juga akan berdampak bagi menurunnya jiwa nasionalisme dan patriotisme.

Peran teknologi dan informasi seakan tidak bisa dilepaskan dalam kehidupan masyarakat hingga semua tergantung dengan adanya teknologi. Masyarakat seakan di suguhkan dengan berbagai kenikmatan dan kemudahan yang disajikan oleh teknologi saat ini hingga mereka terlepas dari peran dan tanggung jawab mereka sebagai bagian dari warga negara masyarakat. Dampak negatif dari perkembangan ini dapat dilihat dari rusaknya moral dan mental masyarakat yang memiliki sifat hedonisme, individualisme, pragmatisme hingga pada ranah paham radikalisme dan 
intoleransi yang berada di berbagai informasi digital saat ini. sebagaimana yang disampaikan Cogan (1998) bahwa terdapat tiga permasalahan global yang dialami oleh berbagai negara di dunia yang meliputi 1) perkembangan ekonomi global, 2) perkembangan teknologi dan komunikasi, 3) meningkatnya populasi jumlah penduduk di dunia yang diikuti dengan adanya permasalahan lingkungan. Ketiga permasalahan ini tentu lahir karena dampak dari peran teknologi dan media informasi yang terus berkembang hingga membentuk peradaban baru yang bisa disebut dengan warga digital.

Konsep kewarganegaraan digital merupakan konsep yang membahas peran warga negara dalam pemanfaatan teknologi dan informasi di berbagai aspek kehidupan manusia. Pemanfaatan teknologi dan media informasi oleh warga negara bisa membentuk persepsi baru yang kemudian disebut dengan kewarganegaraan digital yang menurut Ribble dan Bailey (2011), ada sembilan elemen kewarganegaraan digital yang terdiri dari akses digital, digital commerce, komunikasi digital, digital literacy, etika digital, hukum digital, hak dan kewajiban warga negara digital, kesehatan dan kebugaran digital, dan keamanan digital (hal. 11). Sembilan elemen digital kewarganegaraan digital ini yang harus dikembangkan oleh seluruh negara di dunia untuk bisa mengontrol sekaligus memberikan filter bagi masyarakat dalam memanfaatkan teknologi dan media informasi.

Moral menjadi dasar dalam berkehidupan bermasyarakat berbangsa dan bernegara. Banyak permasalahan global terjadi di dunia juga berawal dari budaya nilai-nilai moral yang belum sepenuhnya diajarkan dan dipahami oleh seluruh bangsa-bangsa di dunia. Karena pada dasarnya moral adalah cerminan dari implikasi perilaku dan sikap warga negara dalam menjalankan tugas dan tanggung jawabnya sebagai warga negara yang baik. Banyak faktor yang merusak moral generasi muda diantaranya perkembangan dan kemajuan teknologi, rendahnya iman, pengaruh pergaulan lingkungan sekitar, rendahnya tingkat kejujuran, hilangnya rasa tanggung jawab sosial, rendahnya tingkat kedisiplinan. Maka dari itu pendidikan moral menjadi landasan dasar utama bagai negara-negara berkembang agar dapat menghasilkan kualitas sumber daya manusia yang profesional dalam upaya membangun peradaban manusia yang lebih baik.

Pendidikan moral menjadi konsep pendidikan utama yang perlu untuk dikembangkan di lembaga pendidikan baik di sekolah dasar maupun perguruan tinggi. Konsep moral menjadi nilai kehidupan manusia yang bersumber pada nilai tatanan kehidupan sosial kemasyarakatan dalam berhubungan berbangsa dan bernegara. Jepang merupakan negara dengan nilai kehidupan sosial tinggi dengan pengembangan nilai moral karakter yang bersumber pada kearifan lokal kebudayaan yang selalu dijunjung tinggi, tidak heran negara Jepang menjadi negara maju di berbagai bidang. Terdapat sepuluh keunggulan negara Jepang dari pada negara lain diantaranya 1) waktu adalah uang sehingga masyarakat Jepang selalu memanfaatkan waktu dengan baik, 2) memiliki prinsip disiplin yang tinggi hingga disebut sebagai negara yang warga negaranya paling disiplin, 3) meski tidak ada semboyan "Kebersihan adalah sebagian dari iman" namun negaranya benar-benar memiliki tingkat kebersihan yang tinggi. 4) negara dengan penghasilan barang elektronik canggih namun justru masyarakat jauh dari gaya hidup konsumerisme, 5) merasa malu saat tidak berprestasi, apalagi kalau pejabat negara yang ketahuan korupsi, 6) memanfaatkan waktu dengan membaca buku, 7) masyarakat Jepang terbiasa dengan hidup mandiri, 8) melindungi negaranya dengan menghargai petani lokal, 9) petugas kebersihan di negara Jepang mendapatkan gaji yang tinggi, 10) pendidikan merupakan aset yang tinggi bagi masyarakat Jepang. Ke sepuluh kelebihan inilah yang kemudian menjadikan negara Jepang menjadi negara yang semakin maju dalam bidang teknologi dan informasi.

Jepang merupakan salah negara dengan tingkat kemajuan teknologi dan media informasi yang begitu baik. Kemajuan teknologi di Jepang justru tidak menjadikan masyarakat Jepang 
memiliki karakter dan moral yang kurang baik. Justru sebaliknya dengan teknologi dan media informasi masyarakat Jepang memiliki semangat dan motivasi untuk terus berkarya dan berinovasi dalam setiap bidang yang digelutinya. Budaya masyarakat jepang seperti inilah yang mejadi sumber filosofis dan ideologis masyarakat Jepang dalam membangun karakter dan kepribadian masyarakat Jepang. Karena bagi masyarakat Jepang budaya adalah sebuah penentu dalam mewujudkan kemampuan suatu negara untuk makmur. Budaya membentuk pemikiran orangorang mengenai risiko, penghargaan, dan kesempatan. Nilai-nilai budaya sangat penting dalam proses kemajuan manusia karena mereka membentuk cara orang-orang berfikir tentang kemajuan (Huntignton, 1996).

Kebudayaan karakter masyarakat Jepang mejadi dasar filosofis masyarakat Jepang dalam membangun peradaban dengan karakteristik yang berbeda dengan peradaban budaya lain. Kebangkitan peradaban Jepang terbentuk dari proses pendidikan karakter moral yang sudah diajarkan sejak dini baik di lingkungan keluarga, sekolah dan masyarakat. Hingga terbentuk pola karakter yang terintegrasi dalam setiap bidang kehidupan masyarakat Jepang dalam menjalankan profesinya masing-masing. Ini tentu dapat dilihat dari tingkat kemodernan budaya Jepang yang begitu maju dibandingkan negara lain khususnya di kawasan ASIA bahkan negara Jepang mampu menyaingi negara-negara lain yakni negara Eropa. Ini terjadi karena masyarakat Jepang menurut Huntington (1996) menemukan nilai-nilai baru di dalam kebudayaan mereka sendiri (hal. 175). Mereka beranggapan bahwa budaya Jepang dan ASIA lainnya lebih unggul dari pada kebudayaan barat. Majunya peradaban Jepang tentu tidak bisa dilepaskan dari peran pendidikan moral karakter yang dibentuk melalui jenjang pendidikan dan diajarkan sejak dini. Maka dari itu perlu dipahami kembali tentang hakikat pendidikan moral dan sistem pendidikan di Jepang.

Pembentukan karakter masyarakat Jepang dalam membangun peradaban manusia tidak bisa dihilangkan dari sistem pendidikan yang mengajarkan nilai-nilai dasar filosofis dan yuridis perkembangan budaya Jepang yang sudah terbentuk melalui peradaban Jepang. Dengan tingkat kualitas sumber daya manusia dan sumber daya belum baik, Jepang mampu membangun peradaban manusia yang lebih baik dengan modal pembinaan karakter pada jenjang sekolah. Melalui pembinaan karakter moral maka akan mampu menjadi bangsa yang unggul. Jepang sangat menyadari pentingnya landasan karakter yang baik bagi manusia dan masyarakat secara langsung. Prinsip nilai moral, norma masyarakat Jepang sangat di junjung tinggi dengan diterapkannya pendidikan moral yang dilakukan di lembaga pendidikan sekolah formal bahkan pendidikan Tinggi.

Pendidikan moral merupakan pendidikan yang dibutuhkan oleh masyarakat modern terutama dalam menghadapi permasalahan kekerasan secara kolektif. Moral dan kewarganegaraan menjadi dasar dalam membangun peradaban budaya manusia. Sebagaimana disampaikan oleh Susana Frisancho dan Guillermo Enrique Delgado (2018) bahwa:

Moral and citizenship education should necessarily include an intercultural perspective. In a global world, people from different cultural backgrounds have to learn to sustain dialogue and co-existence, and build together justice and the common good (hal. 30).

Pendidikan moral merupakan salah satu faktor penentu dalam pembentukan moral karakter masyarakat Jepang. Konsep pendidikan moral pada jenjang sekolah dasar dan menengah diajarkan dalam bentuk buku ajar tentang pendidikan moral yang mengajarkan nilai-nilai moral karakter dalam kehidupan sehari-hari, misalnya disiplin, jujur, tanggung jawab dan paling menarik pembiasaan budaya antre sejak dini. Pembelajaran pendidikan moral menjadi inti dari pendidikan karakter yang diajarkan di berbagai sekolah. Pendidikan moral juga diintegrasikan dalam seluru mata pelajaran di Jepang. Menariknya pendidikan moral di Jepang tidak hanya berhenti pada sekolah menengah atas namun juga tetap diajarkan dalam perguruan tinggi di Jepang. Pendidikan moral di perguruan tinggi bertujuan untuk menyiapkan calon warga negara muda Jepang yang 
memiliki karakter profesional dalam bidangnya masing-masing dengan tetap berpegang teguh terhadap nilai-nilai dasar filosofis masyarakat Jepang yang bermoral dan berkarakter. Karena pada dasarnya nilai karakter yang baik memiliki beberapa komponen diantaranya pengetahuan moral, perasaan moral, dan perilaku moral, maka dari itu konsep karakter moral menjadi tujuan utama dalam sistem pendidikan di Jepang agar mampu menghasilkan kualitas sumber daya manusia profesional yang pada faktanya dapat bersaing negara-negara maju di barat.

Sedangkan di Finlandia pendidikan moral diajarkan sebagaimana konsep pendidikan moral pada umumnya dengan mengajarkan nilai-nilai dasar etika dan nilai norma dalam kehidupan sehari-hari. Berdasarkan penelitiannya Rissanen et al. (2018), dalam upaya pendidikan moral ketika peserta didik melanggar aturan tidak selayaknya menghukum dengan hukum keras, namun harus diberikan pembiasaan dengan memberikan contoh dan ilmu pengetahuan tentang akibat dari pelanggaran hukum tersebut (hal. 11-12). Untuk membentuk profesionalisme guru dalam pendidikan moral sangat diperlukan agar terjadi sinergis antara proses pembelajaran dan pengajaran di kelas. Karena pada hakikatnya proses pendidikan moral tidak hanya sebatas pengajaran akan teori akan dasar-dasar nilai berkehidupan namun juga membentuk karakter dan watak peserta didik dalam membangun nilai-nilai etika dan moral dalam jiwanya.

Demikian gambaran umum dari permasalahan moral serta dampak dari pada perkembangan teknologi dan media infomasi di era globalisasi. Maka diperlukan adanya pendidikan moral yang efektif pada perguruan tinggi sebagaimana yang diterapkan dalam sistem pendidikan di Jepang. Kemudian yang menjadi pertanyaan adalah bagaimanakah konsep pembelajaran pendidikan moral di perguruan tinggi Jepang dan budaya karakter sosial masyarakat Jepang? Tentu hal ini menjadi pokok pembahasan dari penelitian yang akan dilakukan oleh peneliti dan akan dijelaskan secara menyeluruh baik dari tingkat pendidikan moral yang diajarkan serta konsep pendidikan moral yang dikembangkan di perguruan tinggi Jepang, sehingga dapat menjadi bahan evaluasi serta inspirasi dalam mengembangkan konsep pendidikan moral bagi perguruan tinggi di Indonesia.

\section{Metode}

Gagasan tentang aktualisasi pendidikan moral di perguruan tinggi Jepang ini menggunakan metode kualitatif. Hal ini pada dasarnya kajian mengenai pendidikan moral merupakan proses yang membutuhkan analisis deskriptif secara luas. Artinya dalam gagasan ini akan dimunculkan konsep pembelajaran pendidikan moral di perguruan tinggi Jepang serta budaya karakter sosial masyarakat Jepang dengan melakukan pengamatan langsung khususnya pada masyarakat Jepang dan di Universitas Tokyo Gakugei University. Pengolahan dan analisis data dilakukan melalui proses menyusun, mengategorikan data dan mencari kaitan isi dari berbagai data yang diperoleh dangan maksud untuk memperoleh maknanya. Data diperoleh dan dikumpulkan melalui hasil observasi, wawancara dan dokumentasi yang disusun dan dianalisis untuk menjawab pertanyaan masalah yang akan dikaji.

\section{Hasil dan Pembahasan}

Pembelajaran pendidikan moral di Jepang sudah dilaksanakan pada Jenjang sekolah dasar sampai sekolah menegah. Konsep pendidikan moral bertujuan untuk membangun karakter dan metal masyarakat Jepang agar terhindar dari berbagai permasalahan sosial. Dalam kasus ini di Jepang masing memiliki tingkat permasalahan perundungan yang terjadi di tingkat sekolah pertama. Di tahun 2011 terjadi bunuh diri yang dilakukan oleh peserta didik karena mendapat perundungan teman di sekolahnya. Insiden ini ternyata lebih mengejutkan dikalangan pendidikan karena sekolah terjadinya perundungan di sekolah percontohan dalam pengimplementasian pendidikan moral dan terlihat berkomitmen dalam menangani masalah perundungan. Oleh 
karenanya pemerintahan Jepang memutuskan untuk memutakhirkan status kelas moral dengan memperkenalkan pelajaran moral sebagai subjek khusus "('Tokubetsu no Kyouka Doutoku [Doutoku-ka]' hereafter 'Morality as a special subject') (Chyuou Kyouiku Shingika)" (Nishino, 2017, hal. 2).

Pendidikan moral pada lingkup sekolah dasar di Jepang dibagi mejadi beberapa tahapan proses pendidikan karakter dasar yang wajib diajarkan diantaranya yakni menghargai orang lain, diri sendiri, kelompok dan keindahan, kelompok dan komunitas. Keempat komponen dasar pendidikan moral ini diajarkan dan diintegrasikan dalam kehidupan sehari-hari melalui berbagai hal-hal kecil misalnya antre, mencuci piring sendiri, membersihkan rumah, membantu orang tua, dan kegiatan sosial kemasyarakatan yang lain sudah mulai diajarkan sejak dini khususnya pada sekolah dasar. Konsep pendidikan moral ini kemudian dikembangkan kembali pada jenjang sekolah menengah dan juga di perguruan tinggi. Pendidikan Moral di Jepang memberikan kontribusi penting bagi pemahaman ilmiah tentang pendidikan moral sebagai respons terhadap risiko yang dirasakan dari globalisasi di Jepang. Pendidikan moral digunakan sebagai pelindung adanya pengaruh budaya lain yang masuk di negara Jepang (Bamkin, 2018, hal. 127).

Selain pendidikan moral yang direvisi kembali oleh pemerintah. Pemerintah Jepang juga melakukan evaluasi pembelajaran dalam kurun waktu 10 tahun sekali. Evaluasi pembelajaran yang dilakukan oleh pemerintah Jepang setidaknya menjadi inovasi dalam membangun kerangka desain pembelajaran pendidikan moral. Terdapat empat kategori dalam pendidikan moral yang diajarkan yakni (1) pengembangan diri, (2) hubungan dengan orang lain, (3) hubungan ke alam dan leluhur, (4) hubungan dengan komunitas dan masyarakat (Nishino, 2017). Setiap kategori mencakup empat hingga sembilan item, seperti kesederhanaan, kasih sayang, keadilan, dan perhatian alam. Berkenaan dengan perilaku Kelas Moral, sebagian besar guru menggunakan bahan bacaan melibatkan satu nilai utama. Sumber bacaan bahan ajar pendidikan moral dapat dilihat sebagaimana gambar berikut.

Gambar Buku Ajar Pendidikan Moral di Jepang
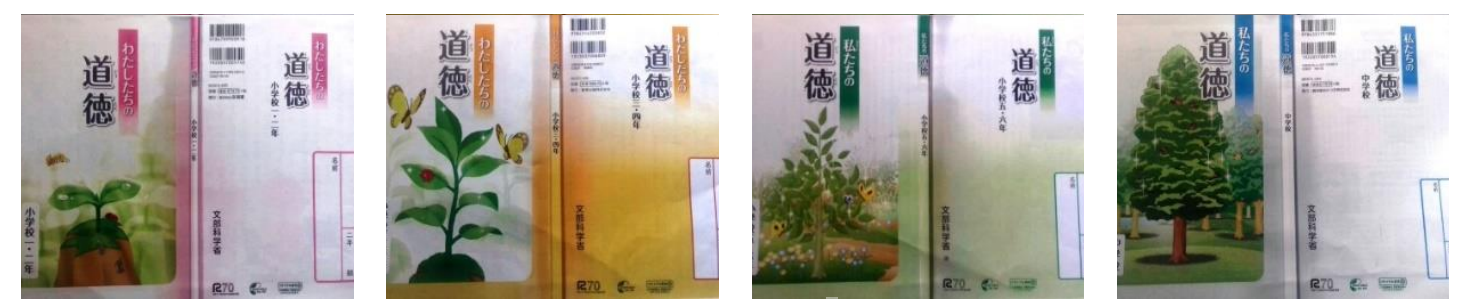

Buku ajar pendidikan moral ini menjadi media dalam mengajarkan nilai-nilai karakter moral sosial masyarakat Jepang. Buku ajar ini memiliki beberapa variasi sesuai tingkat pendidikan yang berlangsung dari sekolah dasar hingga perguruan tinggi, namun memiliki tingkat kajian materi yang berbeda-beda. Bentuk bahan ajar pendidikan moral ini juga digunakan pada masyarakat Korea dalam mengajarkan nilai-nilai moral. Negara Korea juga menggunakan bahan ajar berupa buku teks dalam mengajarkan pendidikan moral dan juga efektif dalam mengajarkan pendidikan moral. Berdasarkan hasil penelitian Han et al. (2018), menunjukkan bahwa terdapat hubungan yang signifikan tentang persamaan dan perbedaan dalam contoh moral antara kedua negara (hal. 1). Dalam hal kesamaan Kedua negara menekankan otonomi moral dan menghormati kehidupan manusia. Dalam kasus perbedaan, Negara Korea hadir figur yang lebih bersejarah sebagai contoh moral, Jepang menghadirkan lebih banyak siswa dan orang biasa sebagai contoh moral. Kita juga membahas implikasi dari perbandingan lintas nasional saat ini dalam buku teks pendidikan moral dari perspektif psikologi sosial dan pendidikan, pendidikan global, dan pendidikan keadilan sosial. Karena beragam contoh berbagi latar belakang sama (misalnya gender, kebangsaan, etnis, peran sosial) lebih efektif dalam mempromosikan persaingan moral dan motivasi moral peserta didik, 
pendidik harus mempertimbangkan dengan hati-hati untuk mempekerjakan para teladan dalam buku teks pendidikan moral.

Perkembangan pendidikan moral tidak selamanya berjalannya dengan lancar beberapa hasil survei menunjukkan bahwa banyak guru pada jenjang sekolah dasar dan sekolah menengah yang belum maksimal dalam upaya penerapan pendidikan moral. Dari 1.360 guru sekolah dasar dan 1262 guru sekolah menengah pertama, 66\% dan 75\% dari mereka masing-masing menjawab Kelas Moral atau pendidikan moral tidak sepenuhnya dilaksanakan. Hal ini karena guru terlalu sibuk pada objek kajian lain serta tidak yakin model pembelajaran yang efektif untuk diterapkan dalam proses pendidikan moral. Sedangkan dari hasil survei lain sejumlah 239 guru di sekolah percontohan (161 di SD sekolah dan 78 di sekolah menengah pertama), 58\% guru sekolah dasar dan 76\% dari sekolah guru SMP merasa bahwa melakukan Kelas Moral adalah 'sulit'. Banyak guru merasa bahwa anak-anak tidak menerapkan hal yang mereka pelajari di Kelas moral dalam kehidupan sehari-hari mereka. Dari survei yang dilakukan selama 20 tahun terakhir, telah ditunjukkan bahwa: 1) siswa, terutama di sekolah menengah pertama, memiliki sikap negatif terhadap moral Kelas; 2) guru merasakan kebutuhan materi yang baik dan cara yang efektif untuk mengajar; dan 3) metode yang digunakan di sebagian besar sekolah telah menjadi stereotip, seperti banyak penekanan pada menanamkan perasaan dan emosi dan tidak memiliki sarana yang efektif untuk mengembangkan penilaian moral dan perilaku moral proaktif (Nishino, 2017, hal. 2).

Pendidikan moral memang tidak mudah dan gampang untuk diajarkan namun pendidikan moral harus terus diimplementasikan pada jenjang pendidikan baik secara langsung maupun tidak langsung. Menurut Iwasa (2017), ada lima poin tertinggi dari konsep moralitas yang dikembangkan dalam pendidikan moral di Jepang yakni

1) freedom from self-centeredness and from the instinct for self-preservation; (2) benevolence extended to all living beings as well as to all humans on earth; (3) heartfelt devotion to the promotion of happiness for all people in the world; (4) respect for our fundamental benefactors for our bodily, social and spiritual existence; and (5) efforts to share a benevolent spirit with other people, and the awareness that we are all members of interdependent networks (hal. 10).

Pendidikan moral dikembangkan dari beberapa konsep dasar pendidikan sosial masyarakat Jepang diantaranya terdiri dari beberapa indikator 1) menganalisis dan menjelaskan beragamnya kekuatan yang telah membantu membentuk orientasi moral Jepang, 2) berikan contoh dan jelaskan pentingnya persatuan budaya dan keanekaragaman melalui pemeriksaan pengambilan keputusan tentang pendidikan moral, 3) merefleksikan nilai dan sikap itu menimbulkan hambatan bagi pemahaman lintas budaya, 4) merenungkan bagaimana orang Jepang membuat keputusan moral dan kekuatan ekonomi, politik, sosial, militer, agama, dan intelektual yang telah membangunnya, 5) mempertimbangkan cara-cara di mana kekuatan ekonomi, politik, sosial, militer, agama, dan intelektual, 6) membahas cara moral pendidikan telah memengaruhi siswa pandangan dunia dan konsepsi mereka tentang individu dalam konteks masyarakat, 7) menyajikan dilema dan eklektik kerangka kerja moral untuk menyarankan alternatif sudut pandang resolusi mereka, 8) terlibat dalam diskusi tentang apa yang merupakan resolusi sah untuk moral, 9) minta siswa mewawancarai orang lain membedakan pengambilan keputusan yang berhubungan dengan moral (Misco, 2010, hal. 66).

Konsep moralitas dasar dalam pendidikan moral ini digunakan sebagai sumber dalam membangun konsep pendidikan moral di Jepang. Kelima dasar moralitas ini di kembangkan pada setiap mata pelajaran yang diintegrasikan pada pendidikan moral. Untuk membangun pendidikan moral yang berorientasi pada nilai-nilai kehidupan maka setiap materi yang diajarkan harus berdasarkan pada empat prinsip dasar berupa (1) mengatasi masalah anak-anak dengan 
konsep sanpouyoshi atau 'kebaikan untuk tiga pihak '(mencari solusi yang baik untuk diri sendiri, untuk anda dan untuk orang lain), (2) komunikasi interaktif antara guru dan, (3) saling bertegur salam, (4) memberikan contoh secara langsung dalam mengajarkan pendidikan moral. Konsep ini mejadi dasar bagi peserta didik untuk membangun dasar materi pendidikan moral untuk diajarkan pada proses pembelajaran di kelas (Iwasa, 2017, hal. 11). Dari uraian di atas dapat diketahui bahwa pendidikan moral yang diterapkan di Jepang sangatlah rinci yang pada akhirnya dapat membentuk karakter orang Jepang yang khas. Namun demikian pendidikan moral juga harus didasari oleh adanya peraturan undang-undang yang mengaturnya, agar terbentuk sinergi yang efektif dalam proses pendidikan moral.

Aktualisasi pendidikan moral di perguruan tinggi Jepang berbeda dengan konsep pendidikan moral pada jenjang sekolah dasar maupun sekolah menegah. Pendidikan moral di perguruan tinggi merupakan kelanjutan dari pendalaman konsep pendidikan moral yang mengarah pada lingkup penanaman moral karakter tanggung jawab dalam menjalankan tugas, hak dan kewajiban sebagai warga negara Jepang yang menjunjung nilai-nilai kearifan lokal. Karakter moral warga negara Jepang disiapkan pada jenjang perguruan tinggi agar mampu dan siap secara profesional dalam menekuni dan bekerja sesuai keahliannya.

Awal mula perkembangan pendidikan moral di Jepang merupakan bagian dari konsep pendidikan kewarganegaraan untuk pendidikan politik dan demokrasi masyarakat Jepang pasca adanya perang dunia ke II. Pendidikan moral dan pendidikan kewarganegaraan menjadi bagian yang tidak di pisahkan dari kehidupan sosial masyarakat Jepang. Hasil penelitian Wray (2000) menunjukkan bahwa pendidikan moral memilki peran lebih penting dari pada pendidikan kewarganegaraan dan pendidikan moral menjadi bagian dalam pendidikan karakter jadi diri bangsa yang berafiliasi dengan nilai kultur budaya masyarakat Jepang (hal. 15). Pendidikan kewarganegaraan yang dikembangkan di negara-negara berat memiliki peran berbeda dengan pendidikan moral. Pendidikan moral sebagai bentuk dari pendidikan sosial dikalangan masyarakat Jepang, untuk mengembangkan karakter nasionalisme dan patriotisme.

Pendidikan moral memang tidak sekadar pendidikan yang mengajarkan akan mana perbuatan baik dan mana perbuatan buruk namun pendidikan moral pada perguruan tinggi memiliki beberapa pedoman diantaranya adalah pertama, pendidikan moral memiliki tujuan untuk membangun karakter warga negara muda yang dapat berpikir bagaimana caranya hidup dan bertindak atas dasar penilaian otonom dan hidup sebagai orang yang proaktif bersama dengan orang lain. Di sisi lain tujuan moralitas ini berorientasi untuk membangun karakter warga negara muda yang reflektif, kritis dan kreatif. Moralitas sebagai kompetensi tidak hanya mencakup penalaran kognitif dalam penilaian moral tetapi juga sensitif terhadap perasaan orang lain. Mengajarkan moralitas sebagai kompetensi adalah dengan mengajar anak-anak berpikir bagaimana memecahkan masalah moral dalam kehidupan nyata situasi. Konsep moralitas ini memberikan kerangka baru untuk pendidikan moral serta mendidik kompetensi moral anak-anak, karena penting untuk memelihara intelektual, keterampilan emosional dan sosial, nilai-nilai dan sikap dengan cara yang seimbang.

Kedua, konten pendidikan moral yang diajarkan berupa penekanan perlunya mengajarkan nilai melalui isu-isu kontemporer, seperti informasi etika, hubungan antara kemajuan ilmu pengetahuan dan bio-etika, perkembangan masyarakat, serta isu-isu yang dihadapi anak-anak dalam masyarakat kontemporer. Ketiga, model pembelajaran yang dikembangkan atas dasar konsep moralitas sebagai subjek khusus dengan penekanan pemikiran dan diskusi untuk meningkatkan pembelajaran lingkungan di kelas. Peran guru untuk mempromosikan pembelajaran aktif di mana mahasiswa berpartisipasi dalam kegiatan pembelajaran proaktif dan kolaboratif yang bertujuan untuk mengidentifikasi dan memecahkan masalah. Pendidikan moral 
menekankan konsep dengan mempromosikan pemecahan masalah dalam berbagai pendekatan, memperkenalkan materi yang memancing diskusi dengan membiarkan mahasiswa mengekspresikannya ide dan pendapat yang kontradiktif dan bertentangan. Oleh karena itu, pendidik didorong untuk berurusan dengan masalah nyata di masyarakat yang akan membantu generasi muda untuk menjadi tertarik dalam belajar moralitas, dan untuk memperoleh pemahaman yang lebih dalam tentang nilai dan kebajikan dalam konteks kehidupan nyata. Pembelajaran aktif melalui kegiatan kelompok yang meningkatkan pembelajaran proaktif dan kolaboratif diharapkan, dapat membangun kepercayaan diri mereka agar dapat memecahkan masalah dalam kehidupan nyata.

Ketiga, bahan ajar yang diterapkan dalam pendidikan moral melalui standarisasi buku teks. Sampai saat ini, Pendidikan moral telah menggunakan berbagai buku sumber daya tambahan dan telah dimasukkan bahan yang dibuat oleh guru itu sendiri. Setiap bahan ajar yang bermuatan materi tentang pendidikan moral harus dievaluasi oleh materi pendidikan sebelum mereka dipublikasikan menjadi buku ajar tentang pendidikan moral yang digunakan oleh pihak sekolah. Keempat, penilaian dan evaluasi pendidikan moral berorientasi pada pengembangan pedoman untuk evaluasi dimana guru didorong untuk fokus pada kualitas dan karakteristik positif anak-anak, dan untuk mencatat perkembangan kompetensi moral setiap anak di kelas. Menurut laporan dari panitia doutoku kyouiku nikakaru hyoukatou no arikata nikannsuru senmonka kaigi yang berdasarkan the expert committee on ways of conducting evaluations for moral education (2016), dikutip Nishino (2017), bahwa tujuan evaluasi ini adalah untuk membuat anak-anak menyadari pertumbuhan mereka sendiri dalam moralitas dan memimpin mereka untuk meningkatkan motivasi belajar (hal. 7). Pada saat yang sama, evaluasi diharapkan untuk melayani para guru, untuk memungkinkan mereka bekerja untuk meningkatkan tujuan, rencana, dan bahan ajar. Karena itu, evaluasi harus dilakukan sebagai berikut yakni: (1) menggunakan gaya deskriptif dan tidak boleh menjadi evaluasi berdasarkan nilai-nilai numerik, (2) melakukan evaluasi bukan dari barang-barang individu, (3) evaluasi harus berupa evaluasi intrapersonal, dan (4) berfokus pada apakah siswa bergerak ke arah yang lebih beragam atau multidimensi.

Menurut Midgette et al. (2018), konsep pendidikan moral memiliki tiga domain yang perlu diajarkan baik di sekolah dasar hingga perguruan tinggi ketiga domain ini terdiri dari (1) integration within the regular middle school history curriculum; (2) alignment with a domain-based approach to moral education; and (3) emphasis upon student trans-active discourse as the mechanism for students' learning and development (hal. 2).

Ketiga domain ini menjadi dasar dalam upaya pengembangan pendidikan moral. Kerangka konseptual pendidikan moral berlaku secara umum yang dikembangkan dalam kerangka kurikulum pendidikan sosial. Kurikulum pendidikan memiliki beberapa kriteria dalam membentuk karakter peserta didik khususnya pendidikan moral sebagaimana yang menjadi ciri pendidikan di Jepang yakni pendidikan mejadi satu kebutuhan penting bagi masyarakat, biaya pendidikan terjangkau oleh seluruh elemen masyarakat namun pendidik tetap mendapat gaji tinggi, tidak terdapat diskriminasi terhadap sekolah, wajib berpendidikan hingga perguruan tinggi.

Pendidikan moral di perguruan tinggi menjadi bekal dalam menyiapkan generasi muda untuk membentuk budaya etika moral yang berlandaskan akan nilai-nilai jati diri bangsa. Hal ini tentu sangat cocok apabila bisa diterapkan dalam proses perkulihan di perguruan tinggi Indonesia. Masih maraknya budaya etika yang belum mengambarkan akan jati diri bangsa menyebabkan negara Indonesia jauh tertinggal dengan negara lain khususnya dalam hal nilai-nilai karakter. Pendidikan moral di perguruan tinggi harus dikembangkan guna menyiapkan generasi muda untuk masuk pada ranah dunia global atau kewarganegaraan global. Internalisasi pendidikan moral pada perguruan tinggi dapat diintegrasikan melalui pendidikan kewarganegaraan global. Karena 
Pendidikan Kewarganegaraan global secara umum memberikan kontribusi untuk membina dan mengembangkan karakter warga negara yang cerdas dan baik. Pembentukan pendidikan kewarganegaraan global tentu harus dilakukan sejak dini, namun demikian pada jenjang sekolah menengah atas dan perguruan tinggi merupakan bentuk proses pembelajaran ideal untuk menerapkan proses pembelajaran pendidikan kewarganegaraan global karena pada jenjang sekolah menengah atas dan perguruan tinggi mampu mengapresiasikan tingkat kemampuan kognitif (Sutrisno, 2018, hal. 50). Dengan demikian, diskusi mengenai cita-cita orang bermoral adalah dasar dari pendidikan moral.

\section{Simpulan}

Pendidikan moral menjadi dasar filosofis masyarakat Jepang dalam membangun peradaban masyarakat Jepang yang berorientasi pada peradaban bangsa yang berkarakter. Budaya karakter masyarakat Jepang terbentuk melalui pendidikan moral baik dari jenjang sekolah dasar sampai perguruan tinggi. Pengembangan pendidikan moral di Jepang sudah terintegrasi dalam setiap mata pelajaran. Pendidikan moral menekankan pada aspek nilai-nilai sosial kemasyarakatan yang berpedoman pada prinsip pengembangan diri, hubungan dengan orang lain, hubungan ke alam dan leluhur, serta hubungan dengan komunitas dan masyarakat. Empat prinsip inilah yang kemudian direkonstruksi pada penerapan pendidikan moral di perguruan tinggi dengan aktualisasi melalui konsep pembelajaran yang terintegrasi mulai dari tujuan pembelajaran, konten pembelajaran, metode pembelajaran, buku teks pembelajaran, serta penilaian dan evaluasi pembelajaran pendidikan moral. Adapun Internalisasi pendidikan moral di perguruan tinggi khususnya di Indonesia dapat diintegrasikan melalui pendidikan kewarganegaraan global yang termuat pada mata kuliah wajib umum Pendidikan Kewarganegaraan karena pendidikan kewarganegaraan secara umum memberikan kontribusi untuk membina dan mengembangkan karakter warga negara yang cerdas dan baik. Hal tersebut tentu sudah menjadi bagian dari ide, instrumentasi dan praksis dalam pendidikan nasional di Indonesia.

\section{Ucapan Terima Kasih}

Terima kasih disampaikan pada Rektor, Dekan FKIP serta lembaga penelitian dan pengabdian kepada masyarakat (LPPM) Universitas Muhammadiyah Ponorogo yang telah mendanai kegiatan penelitian. Terima kasih juga disampaikan pada dosen pengampu mata kuliah kehidupan politik internasional Prof. Dr. Idrus Affandi, S.H. program doktor Pendidikan Kewarganegaraan Universitas Pendidikan Indonesia yang telah mengagendakan kegiatan Field studies to tokyo gakugei university and hiroshima peace memorial museum, sehingga peneliti dapat melakukan penelitian. Terima kasih juga di sampaikan pada Professor Iwata Yasuyuki Deputy President the Curriculum Center for Teacher, Tokyo Gakugei University sebagai narasumber penelitian

\section{Referensi}

Bamkin, S. (2018). Moral education in Japan: Values in a global context. Japanese Studies, 00(00), 1-4. https://doi.org/10.1080/10371397.2018.1438118

Cogan, J., \& Derricott, R. (Ed.). (1998). Citizenship for the 21st century: an international perspective on education. Kogan Page.

Frisancho, S., \& Delgado, G. E. (2018). Moral education as intercultural moral education. Intercultural Education, 29(1), 18-39. https://doi.org/10.1080/14675986.2017.1405214

Han, H., Park, S. C., Kim, J., Jeong, C., Kunii, Y., \& Kim, S. (2018). A quantitative analysis of moral exemplars presented in moral education textbooks in Korea and Japan. Asia Pacific Journal of Education, 38(1), 62-77. https://doi.org/10.1080/02188791.2018.1423950

Huntignton, S. P. (1996). The clash of civilizations and the remaking of world order. Simon and Schuster. https://doi.org/10.4324/9781912282180 
Iwasa, N. (2017). Children's everyday experience as a focus of moral education. Journal of Moral Education, 46(1), 58-68. https://doi.org/10.1080/03057240.2016.1268112

Midgette, A. J., Ilten-Gee, R., Powers, D. W., Murata, A., \& Nucci, L. (2018). Using lesson study in teacher professional development for domain-based moral education. Journal of Moral Education, 47(4), 498-518. https://doi.org/10.1080/03057240.2018.1445982

Misco, T. (2010). Understanding Japan through the lens of moral education. The Social Studies, 95(2), 6266. https://doi.org/10.3200/TSSS.95.2.62-66

Nishino, M. (2017). The challenge of developing meaningful curriculum initiatives for moral education in Japan. Journal of Moral Education, 46(1), 46-57. https://doi.org/10.1080/03057240.2016.1276438

Ribble, M., \& Bailey, G. (2011). Digital citizenship in schools. : International Society for Technology in Education (ISTE). https://doi.org/10.1111/j.1467-8535.2012.01378_9.x

Rissanen, I., Kuusisto, E., Hanhimäki, E., \& Tirri, K. (2018). The implications of teachers' implicit theories for moral education: A case study from Finland. Journal of Moral Education, 47(1), 63-77. https://doi.org/10.1080/03057240.2017.1374244

Sutrisno. (2018). Peran pendidikan kewarganegaraan dalam membangun warga negara global. Citizenship Jurnal Pancasila dan Kewarganegaraan, 6(1), 41-51. https://doi.org/10.25273/citizenship.v6i1.1880

Wray, H. (2000). The fall of moral education and the rise and decline of civics education and social studies in occupied and independent Japan. Japan Forum, 12(1), 15-41.

https://doi.org/10.1080/09555800050059441 